\title{
ETIKA BERPAKAIAN DALAM ISLAM: TINJAUAN BUSANA WANITA SESUAI KETENTUAN ISLAM
}

\author{
Bahrun Ali Murtopo \\ Institut Agama Islam Nahdatul Ulama (IAINU) Kebumen \\ Bahrunalimurtopo@gmail.com
}

\begin{abstract}
Abstrak
Diskursus mengenai konsep etika berbusana dalam Islam, telah menjadi bagian penting doktrin nilainilai keagamaan dalam tradisi skriptual Islam. Pada umumnya wanita muslimah cenderung mengenakan hijab karena memenuhi kewajiban, namun kurang memahami etika berpakaian dalam Islam. Sehubungan dengan hal tersebut, etika berpakaian muslimah dalam Islam, harus dipahami bahwa seorang muslimah hendaknya mempunyai aturan tersendiri dalam berbusana yang dapat menyesuaikan kepantasan dalam lingkungan masyarakat yang ditempati. Berdasarkan analisis kajian ini, makna jilbab (pakaian wanita muslimah) yang benar adalah yang sesuai dengan syariat Islam dan merupakan sesuatu yang menutupi seluruh tubuh wanita muslimah kecuali muka dan telapak tangan. Mengingat, pemakaian jilbab juga menyangkut akhlak kepribadian wanita muslimah.
\end{abstract}

Kata Kunci: Hijab, Wanita, Etika

\section{Pendahuluan}

ara wanita di beberapa belahan dunia mengenal dan memakai busana muslimah,

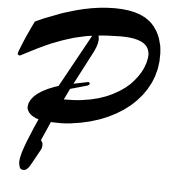

tentunya dengan mode, bentuk, ukuran, corak dan warna, aturan bahkan niat yang berbeda. Fenomena penggunaan busana muslimah di kalangan wanita muslimah, khususnya di Indonesia, mengindikasikan kesadaran muslimah yang tinggi dalam beragama atau hanya sekedar tren berbusana belaka. Sedangkan, pada zaman Jahiliyah, kaum perempuan berjalan dengan keadaan telanjang dada, tidak tertutup oleh apa pun, leher mereka kelihatan, ubun-ubun kepalanya juga kelihatan, bahkan lubang telinganya pun kelihatan. Kemudian Allah SWT., melalui firmanNya mengharamkan kepada para perempuan mukminat berdandan ala jahiliyah terdahulu, dan memerintahkan mereka untuk berdandan dengan dandanan yang berbeda dengan perempuan-perempuan Jahiliyah, baik dari bentuk rambut, tata cara menutup tubuh, tata krama maupun dalam gerak-gerik mereka, yakni dengan menutupkan kain kerudung ke dada mereka. ${ }^{1}$

Meskipun, dilihat dari fenomena kekinian "era modern" ada kecenderungan para muslimah berbusana terkesan keluar dari konteks nilai-nilai ajaran Islam. Barangkali, ini dapat terjadi karena para muslimah itu mengikuti tren, atau memang sebenarnya mereka tidak memahami hukum. Sehingga banyak dari para muslimah yang berpakaian tetapi hakikatnya telanjang, berpakaian tetapi tetap mengundang syahwat, berpakaian tetapi auratnya masih terbuka dan ironisnya mereka tetap percaya diri dengan pakaian yang digunakannya, padahal mereka telah merendahkan martabatnya sendiri di hadapan publik. Sisi lain, juga mengungkapkan bahwa prototype masyarakat modern zaman sekarang pada

\footnotetext{
${ }^{1}$ Shubhi Sulaiman, Shalihah Kiat Mendidik Anak Perempuan dalam Islam, (Semarang: Pustaka Adnan, 2005), 58 .
} 
umumnya sangat menyukai model busana yang memamerkan atau tidak menutup aurat wanita seperti; menggunakan rok mini dan celana ketat merupakan gejala yang tidak dapat dihindari oleh masyarakat modern saat ini. Sesungguhnya kecenderungan model pakaian yang tidak senonoh, ini menunjukan kelemahan moral masyarakat. Termasuk mode berpakaian khususnya bagi wanita muslimah di zaman modern ini selalu mengalami perubahan mode yang disesuaikan dengan live style yang perkembangan zaman.

Ditinjau dari sudut teologi Islam, berbusana muslimah sangat berperan penting dalam kehidupan sosial, dikarenakan ekspektasi kehidupan sosial kemasyarakatan telah mengetahui sisi positif dari berbusana muslimah tersebut yang senantiasa dilakukan dalam kesehariannya, namun sayangnya belum semua orang dapat mengetahui manfaat ataupun pentingnya berbusana muslimah. Secara umum berbusana muslimah dapat dikatakan dalam tahap mementingkan mode yang modern daripada mengikuti aturan Syar'iyyah. Padahal, Islam sebagai Agama rahmatan lil 'alamin (rahmat bagi seluruh alam) mempunyai banyak versi aturan tentang cara berpakaian wanita. Namun, semua aturan yang ada hampir mempunyai hakikat dan tujuan yang sama, yaitu melindungi harga diri dan kehormatan wanita muslimah. Dalam berbusana muslimah, seorang wanita mencerminkan nilai yang ada dalam dirinya. Pemahaman ini pun bermacam-macam, disesuaikan dengan lingkungan dan masyarakat yang memandangnya.

Pakaian (busana muslimah) adalah produk budaya, sekaligus tuntunan agama dan moral. ${ }^{2}$ Dari sini dapat diketahui apa yang dinamai pakaian tradisional, daerah, dan nasional, juga pakaian resmi untuk perayaan tertentu, dan pakaian tertentu untuk profesi tertentu, serta pakaian untuk beribadah. Pada kenyataannya bentuk pakaian yang ditetapkan atau dianjurkan oleh suatu agama, justru lahir dari budaya yang berkembang ketika itu. Namun yang jelas, moral cita rasa keindahan dan sejarah bangsa, ikut serta menciptakan ikatanikatan khusus bagi anggota masyarakat yang antara lain melahirkan bentuk pakaian dan warna-warni kesukaan. Memang unsur keindahan dan moral pada pakaian tidak dapat dilepaskan, tetapi ada masyarakat yang menekankan pada unsur keindahannya. Khususnya dunia Barat, unsur keindahan menjadi nomor satu dan unsur moral jika seandainya mereka pertimbangkan maka tidak jarang telah mengalami perubahan yang sangat jauh dari tuntutan moral agama. Faktanya pun budaya berbusana versi Barat dengan seni keindahanya turut mempengaruhi mindset para muslimah dalam berbusana di era kekinian. Bahkan, pengaruh tren busana Barat ke dunia Timur tidak sedikit, sehingga ada pula masyarakat Timur yang mengikuti mode pakaian Barat, meskipun bertentangan dengan nilai-nilai agama dan budaya masyarakatnya.

Berdasarkan analisa inilah, mereka "para muslimah" seharusnya memahami etika berbusana yang mengedepankan unsur moral, nilai-nilai agama dan mengesampingkan unsur keindahan. Wanita wajib memakai khimar tatkala keluar dari rumahnya, di samping

${ }^{2}$ Quraish Shihab, Jilbab, cet. VI, (Tangerang: Lentera Hati, 2012), 38. 


\section{Etika Berpakaian dalam Islam (Bahrun Ali Murtopo)}

ia juga wajib memakai jilbab yang menutupi khimar-nya. ${ }^{3}$ Sebab, perbuatan demikian lebih menutupi tubuh mereka dan lebih tidak menampakkan bentuk kepala dan lekuk pundak mereka, seperti yang telah dijelaskan. Perintah inilah yang ditetapkan dalam syari'at Islam. Untuk itu, perlu kiranya kita mengetahui pendidikan etika yang terkandung dalam pemahaman berpakaian dalam Islam yang ada pada diri wanita-wanita muslimah di berbagai lapisan masyarakat. Hal ini dapat kita lakukan dengan mengkaji serta menelaah berbaga literasi yang berkaitan dengan etika berpakaian dalam Islam.

\section{Konsep Dasar Etika Berpakaian dalam Islam}

Pakaian (Busana) adalah produk budaya, sekaligus tuntutan agama dan moral. ${ }^{4}$ Memakai pakaian tertutup bukanlah monopoli masyarakat Arab sebelum datangnya Islam, pakaian penutup (seluruh badan wanita) telah dikenal di kalangan bangsa-bangsa kuno dan lebih melekat pada orang-orang Sassan Iran, dibandingkan dnegan tempat-tempat lain. Setelah Islam datang, Al-Qur'an dan Sunnah berbicara tentang pakaian dan memberi tuntunan menyangkut cara-cara memakainya. Kitab Suci Al-Qur'an melukiskan keadaan Adam dan pasangannya sesaat setelah melanggar perintah Tuhan mendekati suatu pohon dan tergoda oleh setan sehingga mencicipinya bahwa:

"(Yakni serta merta dan dengan cepat) tatkala keduanya telah merasakan buah pohon itu, tampaklah bagi keduanya menutupinya dengan daun-daun surga secara berlapislapis". (QS. Al-A'raf [7]:22).

Ayat tersebut mengisyaratkan bahwa Adam as., dan pasangannya tidak sekedar menutupi aurat mereka dengan selembar daun, tetapi daun di atas daun sebagaimana dipahami dari kata (yakhshifani) yang digunakan ayat al-A'raf di atas. Hal tersebut mereka lakukan agar aurat mereka benar-benar tertutup dan pakaian yang mereka kenakan tidak menjadi pakaian mini atau transparan atau tembus pandang. Ini juga menunjukkan bahwa menutup aurat merupakan fitrah manusia yang diaktualkan oleh Adam dan istrinya as. pada saat kesadaran mereka muncul, sekaligus menggambarkan bahwa siapa yang belum memiliki kesadaran seperti anak-anak di bawah umur maka mereka tidak segan membuka dan memperlihatkan auratnya. ${ }^{5}$ Apa yang dilakukan oleh pasangan nenek moyang kita itu, dinilai sebagai awal usaha manusia menutupi berbagai kekurangannya, menghindari dari apa yang dinilai buruk atau tidak disenangi serta upaya memperbaiki penampilan dan keadaan sesuai dengan imajinasi dan khayal mereka. Itulah langkah awal manusia menciptakan peradaban. Allah mengilhami hal tersebut dalam benak manusia pertama untuk kemudian diwariskan kepada anak cucunya. Jika demikian berpakaian atau menutup aurat adalah alamat, bahkan awal dari lahirnya peradabaan manusia.

\footnotetext{
${ }^{3}$ Muhammad Nashiruddin al-Albani, Kriteria Busana Muslimah, (Jakarta : Pustaka Imam Asy-Syafi'i, 2010), 108.

${ }^{4}$ Quraish Shihab, Jilbab , (Jakarta : Lentera Hati 2004), 38.

${ }^{5}$ Quraish Shihab, Jilbab, (Jakarta : Lentera Hati , 2004), 48.
} 
Muslimah sekarang ini banyak yang kehilangan rasa malunya. Mereka mengenakan pakaian yang transparan dan pakaian ketat yang memperlihatkan bentuk dada dan pundak ditambah dengan tidak memakai kerudung. Mereka memperlihatkan tubuh mereka tanpa rasa malu dan takut kepada Allah. Semoga Allah memberi petunjuk kepada mereka untuk kembali ke jalan yang benar dengan menutup aurat dan punya rasa malu, baik kepada Allah swt., maupun kepada sesama manusia. ${ }^{6}$

Ada beberapa aturan syar'i pakaian muslimah yaitu; tidak boleh tipis dan tidak transparan, kecuali ketika di depan suami. Dasar dari syarat ini ialah hadits yang diriwayatkan Aisyah bahwa saudara perempuannya, Asma' binti Abu Bakar datang kepada Rasulullah memakai pakaian menerawang, Rasulullah lantas berpaling darinya dan berkata; "Wahai Asma', jika seorang wanita telah memasuki masa haid maka tidak boleh terlihat darinya, kecuali ini dan ini." Beliau mengisyaratkan pada wajah dan kedua telapak tangan. Sanad hadits ini terdapat Sa'id bin Basyir, dan dia termasuk rawi yang diperselisihkan. Abu Dawud berkata setelahnya, "ini adalah hadits mursal (tidak bersambung sanadnya ) karena Khalid bin Duraik tidak bertemu dengan Aisyah". ${ }^{7}$

Berdasarkan kutipan hadits di atas jelas bahwa Rasulullahtelah menetapkan batas aurat bagi wanita yang sudah baligh, yaitu seluruh tubuhnya, kecuali yang boleh terlihat yaitu wajah dan kedua telapak tangan. Maka, ketika seseorang berjilbab tetapi masih menampakkan apa yang dikecualikan maka cara berjilbab yang demikian adalah kurangtepat. Pakaian ini menampakkan kulit, tidak juga pakaian sangatketat sehingga menampakkan lekak-lekuk badan. Pakaian yang transparan dan ketat, pasti akan mengundang bukan saja perhatian, tetapi bahkan rangsangan. Rasulullah SAW. bersabda bahwa:

"Dua kelompok dari penghuni neraka yang merupakan umatku, belum saya lihat keduanya. Wanita-wanita yang berbusana (tetapi) telanjang serta berlenggaklenggok dan diatas kepala mereka (sesuatu) seperti punuk- punuk unta. Mereka tidak akan masuk surga dan tidak juga menghirup aromanya. Dan (yang kedua adalah)lelaki-lelaki yang memiliki cemeti-cemeti seperti ekor sapi. Dengannya mereka menyiksa hamba-hamba Allah" (HR.Muslim melalui Abu Hurairah).

Berbusana tapi telanjang, dapat dipahami sebagai memakai pakaian tembus pandang, atau memakai pakaian yang demikian ketat, sehingga tampak dengan jelas lekuk-lekuk badannya. Sedang berlenggak-lenggok dan melenggang lenggokkan dalam arti gerakgeriknya berlenggak-lenggok antara lain dengan menari atau dalam arti jiwanya miring tidak lurus atau dan memiringkan pula hati atau melenggak-lenggokkan pula badan orang lain. Adapun yang dimaksud dengan punuk-punuk unta adalah sanggul-sanggul mereka yang dibuat sedemikian rupa sehingga menonjol ke atas bagaikan punuk unta. Sehingga konsep

${ }^{6}$ Ali bin Sa'id Al-Ghamidi, Fikih Wanita (Jakarta: AQWAM 2012), 350.

${ }^{7}$ Ali bin Sa'id Al-Ghamidi ,Fikih Wanita, (Solo : Aqwam Media Profetika, 2015), 349-368. 


\section{Etika Berpakaian dalam Islam (Bahrun Ali Murtopo)}

dasar busana dalam pandangan Islam, menjadi bagian penting yang harus disadari oleh setiap muslimah, tanpa harus terjebak dengan mintsed berbusana gaya Barat yang bertentangan dengan prinsip-prinsi moral dan dasar ajaran Agama Islam.

\section{Tinjauan Busana Wanita Muslimah Sesuai Ketentuan Islam}

Gaya berbusana dalam pandang Islam, semestinya menjadi acuan live style bagi setiap muslimah sejati, terutama dalam mengimplementasikan nilai-nilai dasar keagamaan. Sehubungan dengan hal tesebut, secara umum ada 3 (Tiga) ketentuan tata busana seoarang muslimah yang sesuai dengan tuntunan ajaran Islam, antara lain:

1. Tidak boleh memakai pakaian ketat yang mengundang rangsangan. Kalaulah ditemukan perbedaan pendapat tentang makna ayat 31 surah an-Nur:

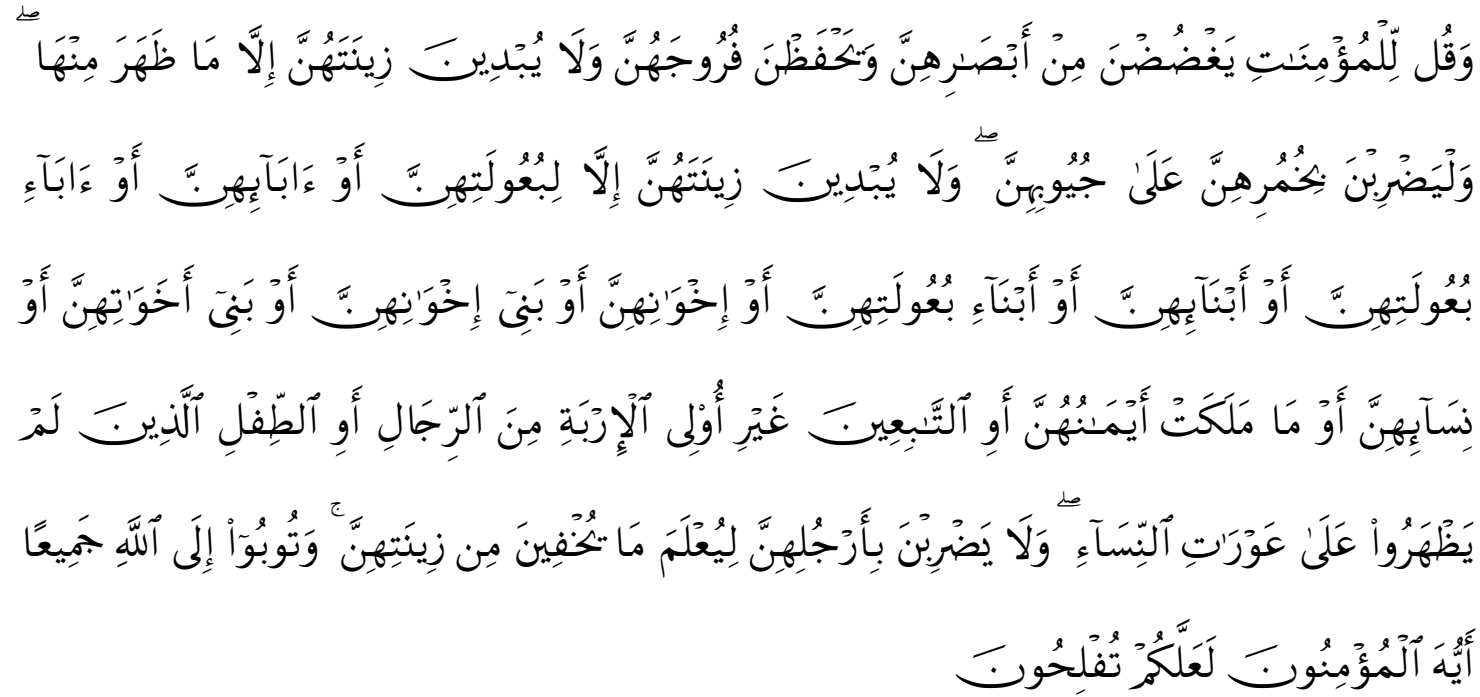

"Katakanlah kepada wanita yang beriman: "Hendaklah mereka menahan pandangannya, dan kemaluannya, dan janganlah mereka menampakkan perhiasannya, kecuali yang (biasa) nampak dari padanya. Dan hendaklah mereka menutupkan kain kudung kedadanya, dan janganlah menampakkan perhiasannya kecuali kepada suami mereka, atau ayah mereka, atau ayah suami mereka, atau putera-putera mereka, atau putera-putera suami mereka, atau saudara-saudara laki-laki mereka, atau putera-putera saudara lelaki mereka, atau putera-putera saudara perempuan mereka, atau wanitawanita Islam, atau budak-budak yang mereka miliki, atau pelayan-pelayan laki-laki yang tidak mempunyai keinginan (terhadap wanita) atau anak-anak yang belum mengerti tentang aurat wanita. Dan janganlah mereka memukulkan kakinya agar diketahui perhiasan yang mereka sembunyikan. Dan bertaubatlah kamu sekalian kepada Allah, hai orang-orang yang beriman supaya kamu beruntung." (QS. AnNur[24]: 31)

Penggalan ayat ini berpesan bahwa segala bentuk pakaian, gerak-gerik, ucapan serta aroma yang bertujuan atau dapat mengundang fitnah (rangsangan birahi) serta 
perhatian berlebihan adalah terlarang. Jadi, wanita yang memakai pakaian transparan dan ketat yang dapat memperlihatkan bentuk tubuhnya dia disebut berpakaian, tetapi telanjang. Ada beberapa ulama pengikut Madzhab Syafi'i memiliki pendapat bahwa seorang wanita dianjurkan memakai pakaian yang longgar dan khimar ketika shalat. Selain itu, hendaklah ia memakai jilbab yang tebal yang melapisi pakaiannya; sehingga jilbab itu menutupi seluruh tubuhnya dan menjadikan bentuk tubuhnya tidak tampak. ${ }^{8}$

2. Tidak memakainya dengan maksud ingin terkenal. Dilarang memakai pakaian yang sangat mahal dan istimewa dengan maksud takabur dan berbangga diri. Atau memakai pakaian lusuh untuk menarik perhatian orang dan supaya disebut tawadhu'. Muslimah memang sebaiknya bersikap tengah-tengah dalam semua urusan agamanya. Nabi dan para istrinya pernah memakai pakaian katun, pakaian dari kapas, pakaian dari kulit, baju kurung, dan pakaian lain yang dikenal masyarakat. Dalam konteks ini juga, Nabi SAW. bersabda:

"Siapa yang memakai pakaian (yang bertujuan mengundang) popularitas, maka Allah akan mengenakan untuknya pakaian kehinaan pada Hari Kemudian, lalu dikobarkan pada pakaian(nya) itu api” (HR.Abu Daud dan Ibn Majah).

Adapaun maksudnya di sini adalah apabila tujuan memakainya mengundang perhatian dan bertujuan memperoleh popularitas. Adapun jika yang bersangkutan memakaianya bukan dengan tujuan itu, lalu kemudian melahirkan popularitas akibat pakaiannya, maka semoga niatnya untuk tidak melanggar dapat menoleransi popularitas yang lahir itu. Sebagaimana perempuan tidak boleh membuka bagian tubuh dibawah dada sampai ke lutut untuk mahramnya dan perempuan lain ketika aman dari timbulnya fitnah. ${ }^{9}$

3. Tidak boleh memakai pakaian bergambar sesuatu yang bernyawa dan bergambar salib.Sekarang ini banyak ditemukan pakaian bergambar makhluk hidup, bergambar salib, dan atau bertuliskan kata-kata tidak sopan dengan berbagai corak dan desain. Lebih lanjut, menurut Muhammad Nashiruddin al-Albani, dalam hal berbusan yang sesuia dengan ketentuan Islam, paling tidak ada beberapa kriteria busana yang mesti diperharikan oleh seorang wanita muslimah. Beberapa kriteria tersebut yaitu ;

1) Menutupi seluruh badan selain bagian yang dikecualikan, hal ini menegaskan bahwa kewajiban wanita untuk menutup seluruh perhiasan dan tidak memperlihatkan sedikit pun darinya kepada laki-laki yang bukan mahramnya.

${ }^{8}$ F. Muhammad Nashiruddin al-Albani, Kriteria Busana Muslimah, (Jakarta: Pustaka Imam AsySyafi'i, 2010), Hal. 168 Hal. 186

${ }^{9} \mathrm{Ahmad}$ Al-Hajji Al-Kurdi, Hukum-Hukum Wanita dalam Fiqh Islam (Semarang: Dina Utama, 1995). 


\section{Etika Berpakaian dalam Islam (Bahrun Ali Murtopo)}

Terkecuali apa-apa yang memang tampak tanpa disengaja, maka ia tidak berdosa apabila segera menutupinya. ${ }^{10}$

2) Tidak berbentuk perhiasan, dalam hal ini sesungguhnya Islam sangat tegas dalam melarang tabarruj, bahkan larangan melakukan perbuatan ini digandengkan dengan larangan melakukan syirik kepada Allah, berzina, mencuri, dan perbuatan-perbuatan lain yang diharamkan. Tabarruj disini ialah perbuatan kaum wanita yang menampakkan perhiasan dan kecantikannya serta segala sesuatu yang wajib ditutupinya, yang dapat mengundang syahwat kaum pria. $^{11}$

3) Harus tebal dan tidak transparan, sebab tujuannya menutup aurat itu baru dapat tercapai jika jilbab terbuat dari kain yang tebal. Kain yangtipis hanya akan menambah fitnah (godaan) dan keindahan bentuk tubuh seorang wanita. ${ }^{12}$

4) Tidak ketat sehingga tidak menampakkan bentuk tubuh, sudah jelas bahwa tujuan berpakaian adalah menghilangkan fitnah dari kaum wanita, dan itu tidak mungkin terwujud melainkan dengan mengenakan pakaian yang longgar dan lebar. Tidak dibolehkan memakai pakaian ketat, sebab meskipun sudah menutupi warna kulit, pakaian tersebut tetap menggambarkan lekuk seluruh tubuh atau sebagiannya. Kondisi seperti ini yang akan mengundang syahwat kaum pria. ${ }^{13}$

5) Tidak boleh diberi wewangian atau parfum, dalam hal ini yang memakai wewangian bagi wanita dapat mengundang syahwat (pria). ${ }^{14}$

6) Tidak menyerupai pakaian laki-laki, dalam hal ini laki-laki yang menyerupai kaum wanita akan terpengaruh oleh akhlak dan perangai kaum wanita sesuai kadar penyerupaannya hingga pada puncaknya laki-laki tersebut benar-benar menjadi banci dan menempatkan dirinya sebagai seorang wanita. Begitu juga dengan wanita yang menyerupai kaum pria akan terpengaruh oleh akhlak dan perangaikaum pria, hingga akhirnya mereka berani bersolek dan menampakkan (perhiasan) sebagaimana kaum pria. ${ }^{15}$

7) Tidak menyerupai pakaian wanita kafir, persyaratan ini berdasarkan prinsip dasar yang telah ditetapkan dalam syari'at bahwa kaum Muslimin,laki-laki dan perempuan, tidak diperbolehkan menyerupakan diri mereka dengan

${ }^{10}$ F.Muhammad Nashiruddin al-Albani, Kriteria Busana Muslimah, (Jakarta : Pustaka Imam AsySyafi'i, 2010), 53.

${ }^{11}$ Ibid., 150-151.

${ }^{12}$ Ibid., Hal 157.

${ }^{13}$ Ibid., 165.

${ }^{14}$ Ibid., 177.

${ }^{15}$ Ibid., 205. 
orang-orang kafir, baik dalam ibadah, hari raya, maupun pakaian yang secara khusus menjadi ciri khas mereka. ${ }^{16}$

8) Tidak berbentuk pakaian Syuhrah (sensasi), maksudnya pakaian Syuhrah adalah semua pakaian yang dipakai dengan tujuan menjadipusat perhatian masyarakat (yang melihatnya) baik berupa pakaian mahal yang dipakai seseorang untuk membanggakan diri dengan kekayaan duniawi maupun pakaian murahan yang sengaja dipakai seseorang untuk menunjukkan sikap zuhud dan itu dilakukan atas dasar riya'. ${ }^{17}$

Berdasarkan uraian tersebut, dapat dipahami bahwa menutup aurat berbeda dengan memakai pakaian syar'i (yang dibenarkan Allah) yang menutup aurat. Dalam sholat, salah satu syarat sahnya adalah menutup aurat, sehingga apa pun yang dipakai seorang Muslimah agar auratnya tidak terbuka, itu sudah cukup menjadikan sholatnya sah. Namun, belum tentu pakaian yang menutupi aurat boleh dikenakan wanita Muslimah saat ia pergi ke luar rumah. Karena untuk keluar rumah, Allah swt., tidak hanya mengahruskan mereka untuk menutup auratnya, tapi juga mengenakan pakaian syar'i untuk menutup auratnya. Saat berada di rumahnya, dalam melakukan aktivitas-aktivitas yang biasa dia lakukan bersama dengan mahramnya, tentu wanita Muslimah tidak perlu menutup aurat dengan pakaian lengkapnya sebagaimana keluar rumah. Karena Allah swt., membolehkan mahram wanita Muslimah itu untuk melihat bagian tubuh wanita sampai batas tempat melekatnya perhiasannya.

"Hijab (busana muslimah) berarti tirai atau pemisah (satir atau fasil) menunjukkan arti

penutup yang ada dirumah Nabi Saw, yang berfungsi sebagai sarana penghalang atau pemisah antara laki-laki dan perempuan, agar mereka tidak saling memandang." 18

Sementara, fashion diciptakan bukan untuk fungsi namun untuk estetika, dirancang bukan untuk melindungi keindahan, namun untuk mengekspos keindahan. Pada hal ini sudah jelas bahwa Hijab (busana muslimah) bukan sebuah fashion, dan fashion bukan bagian dari hijab (busana muslimah). Jilbab adalah kerudung yang dipakai wanita untuk menutupi pakaiannya menurut pendapat yang paling kuat. Jilbab adalah selendang besar yang menutup dari ujung kepala sampai kaki sebelumnya telah saya sampaikan, khimar dipakai dirumah sedangkan jilbab dipakai saat keluar. ${ }^{19}$ Dengan demikian, maka sesunggujnya hakikat Hijab (busana musimah) adalah melindungi keindahan wanita hingga ia tidak menjadi perhatian lelaki. Karena wanita terlalu berharga untuk menjadi bahan perhatian semata.

\section{Penutup}

Etika dalam berpakaian sesuai ketentuan dalam Islam bahwa seorang wanita muslimah hendaklah mempunyai aturan tersendiri dalam berhijab menyesuaikan 'kepantasan' dalam

\footnotetext{
${ }^{16} \mathrm{Ibid}, .209$.

${ }^{17}$ Ibid., 271.

${ }^{18}$ Ensiklopedia Pengetahuan Al-Qur'an dan Hadits. (Jakarta: Kamil Pustaka, 2013), 231.

${ }^{19}$ Muhammad Nashiruddin Al-Albani, Ayo! Berhijab (Solo: Tim Abyan 2013). 119.
} 


\section{Etika Berpakaian dalam Islam (Bahrun Ali Murtopo)}

lingkungan masyarakat yang ia tinggali, jika memang lingkungannya termasuk dalam kondisi Islami. Seorang muslimah sejati sudah seharusnya mengedepankan etika berbusana yang sesuai dengan kententuan ajaran Islam. Pengamalan busana Islam yang dimaksud misalnya; berhijab "Jilbab" yaitu hijab yang benar adalah yang sesuai dengan syari'at Islam dengan memperhatikan criteria hijab seperti; menggunakan khimar yang disebut dengan kerudung panjang yang dapat menutupi dada, atau dada bersama leher mereka, serta Jilbab (pakaian yang menutupi baju dan kerudung yang sedangdipakai) yang disebut jilbab adalah baju, maka ia adalah pakaian yang menutupi tangan dan kakinya. Berbeda jika ia tidak ada keinginan untuk benar-benar menutup aurat dengan 'pantas', ia harus berada dalam lingkungan yang tepat. Dimana masyarakat yang ada tidak mempersoalkan bagaimana seorang wanita muslimah tersebut mengenakan pakaian penutup auratnya.

\section{Daftar Putaka}

Al-Albani, F. Muhammad Nashiruddin. Ayo! Berhijab. Solo: Tim Abyan 2013.

Al-Ghamidi, Ali bin Sa'id. Fikih Wanita. Solo : Aqwam Media Profetika, 2015.

Al-Kurdi, Ahmad Al-Hajji. Hukum-Hukum Wanita dalam Fiqh Islam. Semarang: Dina Utama, 1995.

Ensiklopedia Pengetahuan Al-Qur'an dan Hadits. Jakarta: Kamil Pustaka, 2013.

Maunah, Binti. Landasan Pendidikan. Cet. 1; Yogyakarta: Teras, 2009.

Muntahibun Nafis, Muhammad, Ilmu Pendidikan Islam. Yogyakarta: Sukses Pffset, 2011.

Nashiruddin al-Albani, Muhammad. Kriteria Busana Muslimah. Jakarta: Pustaka Imam Asy-Syafi'i, 2010.

Ramayulis. Ilmu Pendidikan Islam. Cet. 4; Jakarta: Kalam Mulia, 2009.

Roqib, Moh. Ilmu Pendidikan Isla. Yogyakarta: PT LkiS Cemerlang, 2009.

Shihab,Quraish. Jilbab. Jakarta : Lentera Hati 2004. Jilbab. Cet. 6; Tangerang: Lentera Hati, 2012.

Sulaiman, Shubhi. Shalihah Kiat Mendidik Anak Perempuan dalam Islam. Semarang: Pustaka Adnan, 2005. 